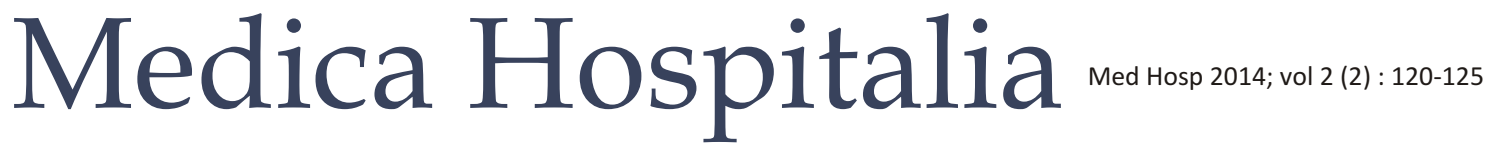

Original Article

\section{Efek Aromaterapi Lavender Inhalasi terhadap Intensitas Nyeri Pasca Sectio Caesaria}

\author{
Wening Dwijayanti*, Sri Sumarni**, Ida Ariyanti*** \\ Politeknik Kebidanan Kemenkes RI, Semarang
}

\begin{abstract}
Abstrak
Latar belakang : Seksio caesaria (SC) adalah melahirkan janin melalui insisi abdomen. Tindakan ini akan berdampak pada ibu yaitu nyeri pasca "Sectio Caesaria". Bidan memiliki peran yang besar dalam penanggulangan nyeri melalui pendekatan non farmakologi, salah satunya dengan pemberian aromaterapi. Penelitian ini bertujuan untuk mengetahui perbedaan intensitas nyeri pasca "Sectio Caesaria". sebelum dan sesudah pemberian aromaterapi lavender secara inhalasi.

Metode : Penelitian ini adalah penelitian pre-eksperimental dengan one group pretest-postest design. Penelitian ini dilaksanakan di Rumah Sakit Dr. Adhyatma, MPH, di kota Semarang selama 2 bulan pada tahun 2013. Sampel sebanyak 32 diambil secara convenience sampling. Intensitas nyeri diukur sebelum dan setelah pemberian inhalasi aromaterapi lavender. Analisis data dengan uji paired t-test.

Hasil : Hasil penelitian menunjukan bahwa sebelum dilakukan pemberian inhalasi aromaterapi lavender rata-rata intensitas nyeri pada skala 5,44 (kisaran 2-9). Sesudah pemberian inhalasi aromaterapi lavender intensitas nyeri mengalami penurunan yaitu rerata skala 4,31 (kisaran $1-7$ ), $p=0,001$.

Simpulan : Terdapat perbedaan intensitas nyeri pasca seksio caesaria setelah pemberian aromaterapi lavender. Bidan dapat mengaplikasikan pemberian aromaterapi sebagai terapi komplementer untuk menurunkan nyeri.
\end{abstract}

Kata kunci : skala nyeri, operasi caesar, aroma terapi lavender.

\section{Effect of inhalation lavender aromatheraphy on pain intensity after caesarian section}

\begin{abstract}
Background : Caesarian Section is the process of a fetus delivery through the abdominal incision. This operating procedure may cause severe pain on the subject. A midwife has a major role to reduce pain through non-pharmacological approaches, one of them is by giving inhalation of lavender aromatheraphy. The purpose of this research is to know the differences of pain intensity on post caesarian section subject, before and after inhalation of lavender aromatherapy.

Methods : This study used a pre-experimental method, with one group pretest-post test design. This study was conducted at Dr. Adhyatma, MPH hospital, Semarang during two months in 2013. There were 32 respondents involving in this study. The sample was recruited by convenience sampling. The pain intensity was scaled before and after giving inhalation of lavender aromatherapy. The data was analysis using a paired t-test.

Results : The results showed that before lavender aromatherapy, mean pain intensity rating scale was 5.44 (range 2-9). But after giving lavender aromatherapy, the pain intensity rating scale significantly decrease, that was 4.31 (range $1-7$ ), $p=0.001$.

Conclusion : There is a difference on post caesarian section pain intensity, before and after giving inhalation of lavender aromatheraphy. It is suggested that midwives are able to applicate aromatherapy for reduce pain intensity.
\end{abstract}

Keywords: Numeric rating scale, caesarian section, lavender aromatherapy.

\section{PENDAHULUAN}

Persalinan merupakan proses membuka dan menipisnya serviks, dimana janin dan ketuban didorong keluar melalui jalan lahir. ${ }^{1}$ Pada proses persalinan terkadang janin tidak bisa lahir secara normal. Sectio caesaria dilakukan karena riwayat seksio, distosia persalinan, distress janin, dan presentasi bokong. ${ }^{2}$ Persalinan Caesaria adalah melahirkan janin melalui insisi pada dinding abdomen (laparatomi) dan dinding uterus (histerotomi). ${ }^{3}$

Menurut Word Health Organisation (WHO), standar rata-rata sectio caesaria di sebuah negara adalah sekitar $5-15 \%$. Di rumah sakit pemerintah rata-rata $11 \%$, sementara di rumah sakit swasta bisa lebih dari $30 \%$. 
Tahun 2004 angka kejadian sectio caesaria di Inggris sekitar 20\% dan 29,1\%. Sedang pada tahun 2001-2003, angka kejadian sectio caesaria di Kanada adalah $22,5 \% .{ }^{4}$

Di Indonesia angka kejadian sectio caesaria juga terus meningkat baik di rumah sakit pendidikan maupun di rumah sakit swasta. Angka kejadian sectio caesaria di Indonesia menurut data survei nasional pada tahun 2007 adalah 921.000 dari 4.039 .000 persalinan $(22,8 \%)$ dari seluruh persalinan. Angka persalinan dengan sectio caesaria di 12 Rumah Sakit Pendidikan berkisar antara $2,1-11,8 \%$. Selain itu berdasarkan penelitian yang dilakukan oleh Basalamah dan Galuardi tahun 1993, terhadap 64 rumah sakit di Jakarta tercatat 17.665 kelahiran, dari angka kelahiran tersebut sebanyak $35,7 \%$ - 55,3\% melahirkan dengan sectio caesaria. Sementara data lain dari RSUPN Cipto Mangunkusumo Jakarta menyebutkan bahwa dari persalinan sebanyak 404 per bulan didapati 30\% persalinan dengan sectio caesaria. Dan dari persalinan sectio caesaria tersebut sekitar $13,9 \%$ merupakan permintaan sectio caesaria yang dilakukan tanpa pertimbangan medis., ${ }^{5,6}$

Persalinan dengan sectio caesaria tersebut akan berdampak bagi ibu dan bayinya. Bagi ibu, menyusui pertama kali setelah bedah caesar sering kali terasa kurang menyenangkan sehingga ibu akan menunda memberikan ASI. Hal ini akibat rahim yang sering berkontraksi karena masih dalam proses kembali ke bentuk semula, juga akibat rasa nyeri yang muncul dari jahitan operasi. Rasa nyeri pada sayatan setelah operasi caesar membuat ibu enggan untuk menggerakan badan, padahal dokter menganjurkan untuk melakukan mobilisasi agar memperoleh kekuatan, kesembuhan, dan memudahkan kerja usus besar dan kandung kemih. ${ }^{5}$ Berdasarkan survei yang dilakukan di RSUP Dr. Kariadi $80 \%$ dari ibu pasca sectio caesaria merasa takut untuk melakukan mobilisasi dini 10 jam pasca sectio caesaria karena takut terjadi sesuatu dengan jahitannya ditambah nyeri jahitan yang masih terasa. $20 \%$ ibu pasca sectio caesaria tidak terlalu takut terjadi sesuatu dengan jahitannya di saat melakukan mobilisasi dini, hanya saja mereka merasakan nyeri. ${ }^{7}$

Secara garis besar ada dua manajemen untuk mengatasi nyeri yaitu manajemen farmakologi dan manajemen non farmakologi. Bidan mempunyai peran yang sangat besar dalam penanggulangan nyeri dengan pendekatan non farmakologi. Manajemen nyeri non farmakologis lebih aman digunakan karena tidak menimbulkan efek samping seperti obat-obatan, karena terapinon farmakologismenggunakan prosesfisiologis. ${ }^{8}$

Penatalaksanaan nyeri secara non farmakologi antara lain dengan cara hipnosis, accupressure, yoga, umpan balik biologis (biofeedback), sentuhan terapeutik, terapi-aroma, suatu penggunaan jamu-jamuan atau uap, kompres panas, mendengar musik dan lain-lain. ${ }^{9}$

Aromaterapi adalah salah satu terapi nyeri dengan pendekatan nonfarmakologi. Aromaterapi merupakan sistem penyembuhan yang melibatkan pemakaian minyak atsiri murni. Terapi ini bisa dilakukan dengan berbagai macam metode seperti pijat, semprotan, inhalasi, mandi, kumur, kompres dan juga pengharum ruangan. Akses aromaterapi melalui hidung (inhalasi) adalah rute yang jauh lebih cepat dibanding cara lain. Terdapat berbagai macam aromaterapi antara lain seperti cendana, kemangi, kayu manis, kenanga, citrus, melati, cengkih, mint, lavender, rose, jasmine dan lain-lain. ${ }^{10,11}$

Aromaterapi pertama diperkenalkan di Inggris pada awal tahun 1990. Efek aromanya dapat menenangkan, menghilangkan rasa cemas dan relaksasi ibu bersalin. Dalam penelitian di Inggris, aroma bunga mawar mempunyai efek yang paling besar, kemudian bunga lavender. ${ }^{10}$ Lavender sebagai analgesik, antiseptik, antidepresan, antispasmodik, antiviral, diuretik, hypotensive. ${ }^{12}$ Lavender juga merupakan minyak yang terpopuler dan paling aman digunakan. Efek aromaterapi positif karena aroma yang segar dan harum merangsang sensori dan akhirnya mempengaruhi organ lainnya sehingga dapat menimbulkan efek yang kuat terhadap emosi. Aromaterapi ditangkap oleh reseptor di hidung, kemudian memberikan informasi lebih jauh ke area di otak yang mengontrol emosi dan memori serta memberikan informasi ke hipotalamus yang merupakan pengatur sistem internal tubuh, sistem seksualitas, suhu tubuh, dan reaksi terhadap stres. ${ }^{11}$

Hasil penelitian Amelia (2008) yang menyatakan bahwa aromaterapi lavender dapat menurunkan intensitas nyeri persalinan kala I. Penelitian ini dilakukan terhadap 18 ibu bersalin kala I, rata-rata nyeri sebelum dan sesudah diberikan aromaterapi lavender adalah 8,11 dan 5,92, sehingga terjadi penurunan intensitas nyeri yang signifikan yaitu $2,19 .{ }^{13}$

Rumah Sakit Dr. Adhyatma merupakan salah satu rumah sakit rujukan dari pelayanan tingkat dasar. Angka persalinan dengan sectio caesaria di Rumah Sakit Dr. Adhyatma dari tahun ke tahun mengalami peningkatan. Berdasarkan data dari ruang Bougenvile Rumah Sakit Dr. Adhyatma pada tahun 2010 terdapat sejumlah 261 persalinan dengan sectio caesaria, tahun 2011 terdapat 322 persalinan dengan sectio caesarea, dan pada tahun 2012 terdapat 575 kasus persalinan dengan sectio caesaria.

Sebagian besar pasien pasca sectio caesaria mengalami intensitas nyeri ringan sampai berat. Berdasarkan hasil studi pendahuluan di ruang Bougenvile Rumah Sakit Dr. Adhyatma dari 10 pasien pasca sectio caesaria didapatkan 4 pasien mengalami nyeri berat, 5 pasien mengalami nyeri sedang, dan 1 pasien mengalami nyeri ringan. Didapatkan 7 dari 10 pasien pasca sectio caesaria enggan dan takut untuk melakukan mobilisasi karena nyeri yang dirasakannya. Tiga pasien juga enggan untuk menyusui bayinya. Berdasarkan hasil wawancara terhadap bidan di ruangan saat ini lebih banyak pasien pasca sectio caesaria yang mau memberikan 
ASI dikarenakan bayi tidak boleh diberikan susu formula di Rumah Sakit Dr. Adhyatma, sehingga meskipun merasa nyeri mereka tetap berusaha untuk memberikan ASI, namun sebenarnya ibu merasa enggan menyusui dikarenakan nyeri yang membuat tidak nyaman. Di Rumah Sakit Dr. Adhyatma penanganan nyeri menggunakan pendekatan farmakologi, biasanya dengan diberikan analgetik, namun penggunaan analgesik secara terus menerus dapat mengakibatkan ketagihan obat. ${ }^{3}$ Meskipun sudah diberikan analgesik pasien masih merasakan nyeri. dibutuhkan kombinasi antara farmakologi dan non farmakologi untuk mengontrol nyeri agar sensasi nyeri dapat berkurang serta pemulihan tidak memanjang. ${ }^{9}$

\section{METODE}

Rancangan penelitian yang digunakan adalah preexperimental design, dengan rancangan one group pretestpost test design.

Populasi dalam penelitian ini adalah seluruh pasien pasca sectio caesaria yang dirawat di ruang Bougenvile RSUD Dr. Adhyatma MPH selama 17 Juni 2013 - 13 Juli 2013 sejumlah 41 responden. Sampel dalam penelitian ini adalah seluruh pasien pasca sectio caesaria yang dirawat di ruang Bougenvile RSUD Dr. Adhyatma MPH selama bulan Juni sampai Juli 2013 yang memenuhi kriteria inklusi. Sampel dalam penelitian ini berjumlah 32 orang. Kriteria dalam penelitian ini adalah yang masih mengalami nyeri, yang dapat berkomunikasi secara verbal, yang sadar penuh, yang tidak mempunyai kontra indikasi terhadap aromaterapi, bersedia menjadi responden.

Teknik sampling dalam penelitian ini adalah convenience sampling yaitu teknik penentuan sampel berdasarkan kebetulan, yaitu siapa saja yang secara kebetulan/insidental bertemu dengan peneliti dapat digunakan sebagai sampel, bila dipandang orang yang kebetulan ditemui itu cocok sebagai sumber data.

Dalam penelitian ini instrumen yang digunakan adalah Skala Numerik (Numerical Rating Scale, NRS).

Jenis data yang dikumpulkan adalah intensitas nyeri pasca sectio caesaria. Pengambilan data intensitas nyeri dilakukan dengan menggunakan skala numerik (Numeric Rating Scale, NRS) sebelum dan sesudah pemberian aromaterapi lavender. Setelah data didapatkan lalu dilakukan pendokumentasian.

Analisis data meliputi univariat untuk menggambarkan intensitas nyeri sebelum pemberian aromaterapi lavender dan sesudah pemberian aromaterapi lavender.

Analisis bivariat untuk mengetahui perbedaan intensitas nyeri pasca sectio caesaria sebelum dan sesudah pemberian aromaterapi lavender secara inhalasi dengan uji paired t-test.

\section{HASIL}

Pengambilan data dimulai pada 17 Juni 2013 - 14 Juli di RSUD Dr. Adhyatma MPH Semarang Tahun 2013. Berdasarkan data intensitas nyeri sectio caesaria pada Tabel 1 responden sebelum pemberian aromaterapi lavender secara inhalasi didapatkan hasil distribusi intensitas nyeri yang bervariasi pada pasien pasca sectio caesaria. Nyeri berada pada skala 2 sampai 9. Tindakan pembedahan, terutama sectio caesaria pada ibu hamil dapat menyebabkan nyeri. Nyeri setelah kelahiran caesaria diakibatkan oleh luka di tempat insisi. Nyeri yang dirasakan terutama terjadi pada hari pertama, dan juga setelah efek bius sudah habis, tetapi tidak semua wanita mempunyai kadar nyeri yang sama. Nyeri yang dirasakan berada pada intensitas dan tingkat keparahan pada masing-masing individu. ${ }^{14}$

Hasil penelitian ini menunjukkan bahwa kondisi nyeri terbanyak yang dirasakan adalah yaitu pada skala 5 (10 responden, 31,3\%). Seperti dikatakan oleh salah satu

\begin{tabular}{|c|c|c|c|c|}
\hline \multicolumn{5}{|c|}{$\begin{array}{l}\text { Distribusi frekuensi intesitas nyeri } \\
\text { pasca sectio caesaria sebelum dan sesudah } \\
\text { pemberian aromaterapi di RSUD Dr. Adhyatma MPH } \\
\text { Tahun } 2013\end{array}$} \\
\hline \multirow[t]{2}{*}{ Skala Nyeri } & \multicolumn{2}{|c|}{ Sebelum } & \multicolumn{2}{|c|}{ Sesudah } \\
\hline & Frekuensi & $\%$ & Frekuensi & $\%$ \\
\hline 1 & 0 & 0,0 & 1 & 3,1 \\
\hline 2 & 1 & 3,1 & 2 & 6,3 \\
\hline 3 & 2 & 6,3 & 5 & 15,6 \\
\hline 4 & 6 & 18,8 & 12 & 37,5 \\
\hline 5 & 10 & 31,3 & 5 & 15,6 \\
\hline 6 & 5 & 15,6 & 4 & 12,5 \\
\hline 7 & 3 & 9,4 & 3 & 9,4 \\
\hline 8 & 4 & 12,5 & 0 & 0,0 \\
\hline 9 & 1 & 3,1 & 0 & 0,0 \\
\hline 10 & 0 & 0,0 & 0 & 0,0 \\
\hline Total & 32 & 100 & 32 & 100 \\
\hline
\end{tabular}

Sumber: data primer

TABEL 2

Rerata intensitas nyeri pasca sectio caesaria sebelum dan sesudah pemberian aromaterapi

\begin{tabular}{lcccc}
$\begin{array}{l}\text { Intensitas } \\
\text { Nyeri }\end{array}$ & Mean & SD & $\boldsymbol{p}$ value & $\boldsymbol{n}$ \\
\hline Sebelum & 5,44 & 1,664 & 0,001 & 32 \\
Sesudah & 4,31 & 1,469 & & \\
\hline
\end{tabular}


responden bahwa nyeri yang dirasakan sangat mengganggu dan menyebabkan ibu enggan menggerakkan badan, apalagi turun dari tempat tidur. Kualitas nyeri yang dirasakan pada masing-masing individu juga bervariasi ada yang melaporkan nyeri seperti tertusuk, ada yang berdenyut, dan lain-lain.

Meskipun belum dilakukan pemberian aromaterapi lavender secara inhalasi terdapat responden yang mengalami kondisi nyeri pada skala nyeri paling rendah yang dirasakan pada angka 2. Hal ini terjadi dikarenakan responden sudah terbiasa menghadapi nyeri sehingga responden lebih siap dan mudah mengantisipasi nyeri. ${ }^{15}$

Sesudah dilakukan pemberian aromaterapi lavender secara inhalasi selama 15 menit dengan menggunakan tissue dan dengan tarikan napas dalam, terdapat penurunan intensitas nyeri, meskipun tidak semuanya mengalami penurunan yang signifikan. Adapula yang tidak mengalami penurunan nyeri yaitu sebanyak 4 responden yang tidak mengalami penurunan nyeri sama sekali. Nyeri berada antara skala nyeri 1 sampai skala nyeri 7.

Sesudah pemberian aromaterapi lavender secara inhalasi kondisi nyeri terbanyak yang dirasakan oleh responden adalah pada skala 4. Meskipun sudah dilakukan pemberian aromaterapi kondisi nyeri terberat yang dirasakan responden berada pada skala 7. Hal ini kembali kepada subyektivitas dan persepsi responden terhadap nyeri, bahwa hanya klienlah yang paling mengerti dan memahami tentang nyeri yang dirasakan. Selain itu terdapat beberapa faktor yang dapat mempengaruhi persepsi dan reaksi masing-masing individu terhadap nyeri. Faktor-faktor yang dapat berpengaruh adalah usia, jenis kelamin, perhatian, ansietas (kecemasan), dan keletihan. ${ }^{15}$ Usia sangat berpengaruh terhadap toleransi nyeri seseorang. Umumnya semakin bertambah usia semakin bertambah toleransinya terhadap nyeri. Selain itu jenis kelamin wanita dianggap lebih sering mengeluh nyeri daripada laki-laki yang mana hal ini dipengaruhi oleh faktor budaya. Sedangkan perhatian dan ansietas yang meningkat juga meningkatkan persepsi terhadap nyeri. Keletihan atau kelelahan yang dirasakan seseorang juga akan meningkatkan sensasi nyeri dan menurunkan koping individu. ${ }^{15,16}$ Namun peneliti tidak meneliti sampai faktor-faktor yang mempengaruhi terjadinya nyeri.

Responden yang merasakan nyeri skala paling ringan adalah pada skala 1 . Responden yang mengalami penurunan nyeri menyatakan bahwa sangat menyukai bau aromaterapi lavender, mereka menyatakan bahwa di rumah sakit sering kali mencium bau pembersih lantai (yurizol) yang terkadang membuat mual dan tidak nyaman para pasien. Ketika menghirup aromaterapi lavender yang diteteskan pada tissue responden merasakan lebih nyaman, tenang, dan nyeri yang dirasa terlupakan. Hal ini sesuai dengan penelitian yang menyatakan bahwa dalam lavender terkandung senyawa linalyl asetat dan linanolol (C10H18O) yang berperan dalam relaksasi. ${ }^{17}$

Pembuktian hipotesis adanya perbedaan intensitas nyeri pasca sectio caesaria sebelum dan sesudah pemberian aromaterapi lavender secara inhalasi menggunakan uji paired t-test dikarenakan data yang berdistribusi normal. Hasil penelitian didapatkan $p$ value $0,001(<0,05)$ dan hasil $t_{\text {hitung sebesar } 9,000}\left(>t_{\text {tabel }}=2,042\right)$ yang berarti ada perbedaan yang signifikan antara sebelum dan sesudah pemberian aromaterapi lavender secara inhalasi. Hal ini sesuai teori yang menyatakan bahwa aromaterapi dapat membantu mengurangi intensitas nyeri pasca sectio caesaria. Inhalasi Lavender berperan dalam mengurangi rasa sakit dan mempunyai kasiat psikologi menenangkan., 91,17

Penelitian lain yang mendukung dengan hasil penelitian ini adalah penelitian Amelia yang menyatakan bahwa aromaterapi lavender dapat menurunkan intensitas nyeri persalinan kala I. Selain itu penelitian yang dilakukan oleh Frayusi juga menyatakan bahwa aromaterapi mampu untuk menurunkan intensitas nyeri pada klien dengan infark miokardium di RSUP Dr. M Djamil Padang. Hal ini dimungkinkan karena aromaterapi tersebut bekerja pada sistem limbik yang mengatur emosi, saraf dan juga hormon. .3,17,18 $^{2}$

Perjalanan masuknya aromaterapi, ketika minyak atsiri dalam hal ini adalah aroma lavender dihirup, molekul yang mudah menguap (volatile) dari minyak tersebut dibawa oleh arus udara ke "atap" hidung dimana silia-silia yang lembut muncul dari sel-sel reseptor. Ketika molekul-molekul itu menempel pada rambut-rambut tersebut, suatu pesan eletrokimia akan ditransmisikan melalui bola dan saluran olfaktory ke dalam sistem limbic. Hal ini akan merangsang memori dan respons emosional. Hipotalamus berperan sebagai relay dan regulator, memunculkan pesan-pesan yang harus disampaikan ke bagian otak serta bagian badan yang lain. Pesan yang diterima itu kemudian diubah menjadi tindakan yang berupa pelepasan senyawa elektrokimia yang menyebabkan euphoria (kesenangan yang berlebihan), relaks atau sedatif. ${ }^{11,17}$ Sistem limbik ini terutama digunakan dalam ekspresi emosional.

Berdasarkan penelitian di Universitas Warwick di Inggris, bau yang dihasilkan aromaterapi akan berikatan dengan gugus steroid di dalam kelenjar keringat, yang disebut osmon, yang mempunyai potensi sebagai penenang kimia alami. Respon bau yang dihasilkan akan merangsang kerja sel neurokimia otak. Sebagai contoh, bau yang menyenangkan akan menstimulasi thalamus untuk mengeluarkan enkefalin yang berfungsi sebagai penghilang rasa sakit alami dan menghasilkan perasaan sejahtera. ${ }^{18,19}$ Hal ini sesuai dengan pernyataan beberapa responden yang ketika mencium atau menghirup aromaterapi lavender yang diteteskan pada tissue, 
responden merasakan ketenangan, dikarenakan aromanya yang harum dan segar.

Berdasarkan hasil penelitian ini mean rata-rata antara sebelum dengan sesudah pemberian perlakuan mengalami penurunan, sebelum pemberian mean ratarata sebesar 5,44 kemudian sesudah pemberian aromaterapi menjadi 4,31. Penurunan nyeri rata-rata antara sebelum dan sesudah pemberian aromaterapi lavender secara inhalasi adalah sebesar 1,13. Hal ini menyatakan bahwa aromaterapi akan merangsang keluarnya hormon enfekalin, serotonin dan endorfin. ${ }^{18,19,20}$ Enkefalin dianggap dapat menimbulkan hambatan presinaptik dan hambatan pasca sinaptik pada serabut-serabut nyeri tipe $\mathrm{C}$ dan tipe delta A dimana mereka bersinaps di kornu dorsalis. Proses tersebut mencapai inhibisi dengan penghambatan saluran kalsium. Penghambatan nyeri tersebut yaitu dengan memblok reseptor nyeri sehingga nyeri tidak dikirim ke korteks serebri dan selanjutnya akan menurunkan persepsi nyeri. ${ }^{21,22}$ Sesuai dengan teori gate control yang dikemukakan oleh Melzack dan Wall bahwa impuls nyeri dihantarkan saat sebuah pertahanan dibuka dan impuls nyeri dihambat saat sebuah pertahanan ditutup, sehingga dapat menurunkan intensitas nyeri yang dirasakan. ${ }^{16,17,23,24}$

\section{SIMPULAN}

Sebelum dilakukan pemberian aromaterapi lavender secara inhalasi, intensitas nyeri rata- rata yang dirasakan responden adalah pada skala 5,44. Nyeri tertinggi yang dirasakan responden yaitu pada skala 9 , sedangkan yang terendah pada skala 2.

Sesudah dilakukan pemberian aromaterapi lavender secara inhalasi intensitas nyeri mengalami penurunan yaitu rata-rata mengalami intensitas nyeri pada skala 4,31 Nyeri tertinggi yang dirasakan pada skala 7 , sedangkan yang teringan pada skala 1 .

Ada perbedaan intensitas nyeri pasca sectio caesaria sebelum dan sesudah pemberian aromaterapi inhalasi. Hal ini ditunjukan dengan hasil analisis penelitian yaitu didapatkan penurunan rata-rata sebesar 1,13 dengan nilai thitung sebesar 9,000 ( $\left.t_{\text {hitung }}>2,042\right)$ dan Asymp.sig (2-tailed) sebesar 0,001 ( $p<0,05)$.

Petugas kesehatan RSUD Dr. Adhyatma MPH terutama pembuat kebijakan di rumah sakit sebaiknya memberikan kebijakan kepada perawat ataupun bidan untuk mengaplikasikan pemberian aromaterapi sebagai terapi komplementer kepada pasien pasca sectio caesaria sehingga dapat membantu menurunkan nyeri yang dirasakan sesuai dengan hasil penelitian.

Perlu penelitian lanjutan tentang perbedaan intensitas nyeri pasca sectio caesaria sebelum dan sesudah pemberian aromaterapi lavender secara inhalasi dengan menambahkan kelompok kontrol yaitu dengan menggunakan aromaterapi jenis lain dan membandingkannya manakah yang lebih efektif untuk menurunkan nyeri. Perlu penelitian yang lebih lanjut dengan memperhatikan faktor-faktor yang mempengaruhi terjadinya nyeri seperti usia, kecemasan, perhatian, keletihan, dan lain-lain.

Sebaiknya ibu pasca sectio caesaria bersedia menggunakan aromaterapi sebagai terapi komplementer dalam rangka mengurangi efek nyeri yang timbul.

Masyarakat ikut berpartisipasi memberikan dukungan moral pada ibu pasca sectio caesaria untuk menggunakan aromaterapi sehingga ibu pasca sectio caesaria merasa lebih nyaman dan tenang selama proses pemulihan dan nifas.

\section{ACKNOWLEDGEMENT}

1. Direktur, Ketua Jurusan Kebidanan, Ketua Prodi DIV Bidan Pendidik, Segenap Dosen dan staf Politeknik Kesehatan Kementerian Kesehatan Semarang.

2. Direktur, bidan sejawat dan staf karyawan RSUD Dr. Adyatma Semarang

3. Ibu, bapak, anak-anak dan keluarga yang selalu memberi semangat dan dukungan.

4. Responden dan keluarga yag terlibat dalam penelitian ini serta semua pihak yang tidak dapat disebutkan satu per satu.

\section{DAFTAR PUSTAKA}

1. Prawirohardjo, S. 2009. Ilmu Kebidanan. Jakarta: Bina Pustaka

2. Leveno, K, et al. 2009. Obstetri William Panduan Ringkas. Terjemahan Brahm U. Jakarta: EGC

3. Cunningham. 2005. Obstetri William. Jakarta: EGC

4. Dewi, Y. 2007. Operasi Caesar, Pengantar dari A sampai Z. Jakarta: EDSA Mahkota

5. Kasdu, D. 2003. Operasi Caesar Masalah dan Solusinya. Jakarta: PuspaSwara

6. Rizky. 2012. Hubungan Pre Eklampsia Berat dengan Kejadian Sectio Caesaria. dalam http://Riskydede.blogspot.com (19 maret 2013)

7. Fauziyah, Y. 2012. Tingkat Kecemasan Ibu Nifas 10 Jam Pasca Sectio Caesaria di RSUP Kariadi Tahun 2012. Karya Tulis Ilmiah. Semarang: Poltekkes Kemenkes Semarang

8. Mander, R. 2004. Nyeri Persalinan. Jakarta: EGC.

9. Bobak, dkk. 2004. Buku ajar keperawatan maternitas terjemahan Maria A. Jakarta: EGC

10. Dean, S. 2007. Aromaterapi (Pedoman menjadi Sehat bagi Orang Sibuk). Jakarta: EGC

11. Koensoemardiyah. 2009. A-Z Aromaterapi untuk Kesehatan, Kebugaran dan Kecantikan. Yogyakarta: Lily Publisher

12. Tiran, D \& Mack, S. 2000. Complementary Therapies for Pregnancy and Childbirth. London: Hartcourt Publisher

13. Amelia, S. 2008. Efektivitas Aromaterapi Lavender terhadap Penurunan Intensitas Nyeri Kala I. Jurnal FDK. Medan:FDK

14. Reeder, S \& Martin, L. 2011. Keperawatan Maternitas: Kesehatan wanita, bayi dan keluarga, terjemahan Eka Anisa. Jakarta:EGC

15. Prasetyo, S.N. 2010. Konsep dan Proses Keperawatan Nyeri. Yogyakarta: Graha Ilmu 
16. Potter \& Perry. 2005. Fundamental Keperawatan Volume 2. Jakarta: EGC

17. Dewi, I P. 2011. Aromaterapi Lavender Sebagai Media Relaksasi. Artikel. Bali: Bagian Farmasi Universitas Kedokteran Udayana

18. Poerwadi, R. 2006. Aromaterapi Sahabat Calon Ibu. Jakarta: Dian Rakyat

19. Frayusi, Anif. 2011. Pengaruh Pemberian Terapi Wewangian Bunga Lavender (Lavandula Angustifolia) Secara Oles Terhadap Skala Nyeri Pada Klien Infark Miokardium Di Cvcu RSUP. Dr. M Djamil Padang Tahun 2011. Skripsi. Padang: Universitas Andalas

20. Primadiati, R. 2002. Aromaterapi Perawatan Alami untuk Sehat dan Cantik. Jakarta: PT Gramedia Pustaka Utama

21. Gondo, H K. 2011. Pendekatan Non Farmakologi untuk Mengurangi Nyeri saat Persalinan. Artikel. Surabaya: FK Wijaya Kusuma

22. Candra, A. 2012. 6 Cara Penyembuhan Tanpa Obat Kimia. Artikel. Dalam http:/ / health.kompas.com(17/05/2013)

23. Muttaqin, A. 2008. Buku Ajar Asuhan Keperawatan Klien dengan Gangguan Sistem Persarafan. Jakarta: Salemba Medika

24. Guyton A. C., Hall J. E.. 2007. Buku Ajar Fisiologi Kedokteran. Jakarta: EGC 